\title{
PELATIHAN DAN PENDAMPINGAN PAJAK UMKM GUNA MENDORONG MASYARAKAT SADAR PAJAK DI KOTA CILEGON
}

\author{
Intan Puspanita ${ }^{1}$, Asih Machfuzhoh ${ }^{2}$, Refi Pratiwi ${ }^{3}$ \\ ${ }^{1,2,3)}$ D III Perpajakan, Fakultas Ekonomi dan Bisnis Universitas Sultan Ageng Tirtayasa \\ e-mail: intan.puspanita@untirta.ac.id
}

\begin{abstract}
Abstrak
Kegiatan pengabdian pada masyarakat ini bertujuan untuk mengenalkan tentang peraturan perpajakan pada UMKM, serta membantu pelaku usaha UMKM dalam menghitung, memperhitungkan, menyetor, dan melaporkan sendiri kewajiban pajaknya dengan benar agar dapat memenuhi kewajiban perpajakannya dan meningkatkan kesadaran dan pentingnya UMKM dalam pembangunan negara. Metode dalam kegiatan pengabdian ini dilakukan dalam beberapa tahap. Tahap pertama yaitu melakukan sosialisasi mengenai peran UMKM dalam pembangunan, sehingga dapat meningkatkan kesadaran dan pengetahuan pelaku UMKM mengenai peran mereka akan pentingnya pajak dalam pembangunan negara. Tahap kedua yaitu sosialisasi alasan membuat NPWP dan pelatihan cara pembuatan NPWP agar dapat meningkatkan pemahaman pelaku UMKM tentang kegunaan dari NPWP dalam pelaporan kewajiban perpajakannya. Tahap ketiga yaitu praktik pelaksanaan kewajiban perpajakan mulai dari menghitung menyetorkan dan melaporkan pajak. Berdasarkan kegiatan yang telah dilakukan menemukan alasan UMKM tidak membuat NPWP karena tidak mengetahui cara pembuatannya dan keterbatasan informasi terkait syaratsyarat apa saja yang diperlukan dalam pembuatan NPWP tersebut, pelaku UMKM belum melakukan pencatatan keuangan secara lengkap dan masih ada yang belum paham dalam melakukan pencatatan laporan keuangannya karena beberapa masih bingung cara menghitung dana melapor pajaknya dan berpendapat bahwa omset usahanya masih sangat minim sehingga mereka masih belum melaporkan pajak UMKM dan mereka belum memahami terakit PP No 23 tahun 2018.
\end{abstract}

Kata Kunci: NPWP, Pajak, PP No 23 tahun 2018, UMKM.

\begin{abstract}
This activity aims to introduce tax regulations to MSMEs, as well as to assist MSME business in calculating, depositing, and reporting their own tax obligations correctly in order to fulfill their tax obligations, increase awareness and importance of MSMEs in state development. The method that used of this activity is carried out in several stages. First is to conduct socialization regarding the role of MSMEs in development, so as to increase awareness and knowledge of MSME actors regarding their role of the importance of taxes in state development. The second stage is the socialization of the reasons for making NPWP and training on how to make NPWP in order to increase the understanding of MSME actors about the use of NPWP in reporting their tax obligations. The third stage is the practice of implementing tax obligations starting from calculating depositing and reporting taxes. Based on the activities that have been carried out, it has found that the reasons for MSMEs not making NPWPs are because they do not know how to make them and limited information regarding what conditions are needed in making the NPWP, MSMEs have not carried out complete financial records and there are still those who do not understand how to record reports money because some are still confused about how to calculate the funds to report their taxes and think that their business turnover is still very minimal so they still have not reported MSME taxes and they do not understand PP No. 23 of 2018.
\end{abstract}

Keywords: NPWP, Regulation Number 23 of 2018, MSME 


\section{PENDAHULUAN}

Indonesia membutuhkan penerimaan negara dalam jumlah besar untuk menopang pembiayaan pembangunan nasional dalam segala sektor. Dua komponen utama yang menjadi sumber penerimaan dalam negeri yaitu penerimaan pajak dan penerimaan negara bukan pajak. Pajak berfungsi sebagai alat untuk mengumpulkan dana (budgetair) yang akan digunakan untuk membiayai berbagai macam pengeluaran pemerintah. Pajak merupakan modal investasi yang menunjukan kemandirian suatu negara, karena sifatnya yang dapat dipaksakan dan merupakan iuran yang wajib dibayarkan oleh setiap warga masyarakat dengan ketentuan yang mengikat (Tandilino, 2016). Seiring terwujudnya kemandirian bangsa, maka peranan pajak sangatlah penting untuk mewujudkan kesejahteraan masyarakat yang lebih baik.

Usaha Mikro Kecil dan Menengah (UMKM) semakin menunjukkan perannya dalam pertumbuhan ekonomi negara. Dominasi sektor UMKM dalam beberapa tahun terakhir semakin meningkat. Pada tahun 2018, jumlah unit usaha UMKM tercatat sebanyak 99,99\% dari total unit usaha dengan serapan tenaga kerja sebanyak 97\% dari total tenaga kerja. UMKM juga telah menyumbangkan 61,07\% dari jumlah Produk Domestik Bruto (Kementerian Koperasi dan Usaha Kecil dan Menengah, 2018). Dengan jumlah pelaku UMKM yang semakin besar dan kontribusinya terhadap PDB Indonesia mencapai 61\%, maka diproyeksikan masih banyak potensi pajak yang dapat digali.

Untuk meningkatkan penerimaan pajak dari sektor UMKM, Pemerintah mengeluarkan berbagai kebijakan baik dari segi peraturan maupun pemberdayaan. Di sisi aturan, pemerintah memberikan insentif kepada pelaku UMKM dengan menurunkan tarif pajak penghasilan final (PPh Final) menjadi $0,5 \%$ dari sebelumnya $1 \%$ dari total omzet atau penghasilan bruto. Revisi aturan ini dituangkan dalam Peraturan Pemerintah (PP) Nomor 23 tahun 2018 yang menggantikan PP Nomor 46 Tahun 2013 tentang Pajak Penghasilan atas Penghasilan dari Usaha yang Diterima atau Diperoleh Wajib Pajak yang Memiliki Peredaran Bruto Tertentu (Firmansyah, 2019). Dengan diberlakukannya PP No 23 tahun 2018 diharapkan masyarakat dapat berpean aktif dalam kegiatan ekonomi. Menurut Sri Mulyani dalam (okefinance.com) pada tahun 2018, kontribusi UMKM sebesar Rp5,8 triliun dari total penerimaan pajak sebesar Rp1.315,9 triliun. Namun, dari angka tersebut dirasa masih kurang kontribusinya. Hal ini diyakini karena wajib pajak masih merasa kesulitan dalam kewajiban perpajakannya. Oleh karena itu, diperlukan adanya pelatihan dan pendampingan pajak bagi pelaku UMKM agar dapat meningkatkan kesadaran wajib pajak dalam memenuhi kewajiban perpajakannya.

Kebutuhan pelatihan dan pendampingan pajak bagi UMKM dilakukan karena peraturan pemerintah nomor 23 tahun 2018 bagi UMKM yang memiliki omzet di bawah Rp 4,8 dengan tarif 0,5\% hanya berlaku selama 7 (tujuh) tahun untuk UMKM Orang Pribadi dan 3 (tiga) tahun untuk UMKM badan. Setelah itu perlakukan perpajakan UMKM yang memiliki omzet di bawah Rp 4,8 milyar adalah sama dengan usahawan lainnya yang memiliki omzet di atas Rp4,8 milyar. Artinya, perhitungan PPh 21 UMKM OP atau badan mengikuti UU PPh Pasal 17, yakni dikenakan tarif progresif dari laba kena pajak. Hal ini tentu akan berdampak besar terhadap adiministrasi perpajakan yang harus dipersiapkan oleh UMKM OP maupun badan (Sandra, 2019).

Pemahaman kewajiban perpajakan telah diulas oleh beberapa penelitian. Fitria \& Supriyono (2019) menemukan bahwa pemahaman UMKM atas peraturan perpajakan berpengaruh positif terhadap kepatuhan pelaku UMKM dalam membayar pajak. Hal ini sejalan dengan penelitian Mustofa, Kertahadi \& R Maulinarhadi (2016) yang menyatakan bahwa pemahaman peraturan perpajakan secara parsial berpengaruh siginifikan terhadap kepatuhan wajib pajak. Putri, Saerang dan Budiarso (2019) menemukan bahwa tingkat pemahaman wajib pajak UMKM di Kota Tomohon tergolong cukup baik, namun, kewajiban menghitung, membayar dan melaporkan wajib pajak UMKM di Kota Tomohon masih rendah, berbanding terbalik dengan kemauan wajib pajak. Berdasarkan hasil penelitian-penelitian tersebut membuktikan bahwa pemahaman dan pengetahuan pajak UMKM berpotensi pada pelaksanaan kewajiban perpajakannya. Namun, untuk mendukung pengetahuan dan pemahaman tersebut, UMKM masih membutuhkan bimbingan dan informasi perpajakan. 
Tabel 1.1 Kelompok Sasaran dan Potensi/Permasalahan UMKM di Kota Cilegon

\begin{tabular}{|l|l|}
\hline \multicolumn{1}{|c|}{ Kelompok Sasaran } & \multicolumn{1}{|c|}{ Potensi/Permasalahannya Dari Berbagai Aspek } \\
\hline & $\begin{array}{l}\text { - Masih kurangnya pengetahuan pajak bagi UMKM } \\
\text { - UMKM belum memiliki NPWP dan tidak mengetahui cara } \\
\text { pembuatannya }\end{array}$ \\
$\begin{array}{l}\text { UMKM yang berada di } \\
\text { Kota Cilegon }\end{array}$ & $\begin{array}{l}\text { UMKM masih belum mampu menghitung pajak atas } \\
\text { penghasilan usahanya } \\
\text { - Pelaku UMKM belum mampu menyetor dan melaporkan } \\
\text { pajak atas penghasilan usahanya menggunakan sistem e- } \\
\text { filling }\end{array}$ \\
\hline
\end{tabular}

Berdasarkan tabel 1.1 di atas maka diperlukan kegiatan pengabdian kepada masyarakat berupa pelatihan dan pendampingan pajak UMKM masih sangat penting dilakukan. Tujuan dari pelatihan dan pendampingan pajak UMKM ini adalah untuk mengenalkan tentang peraturan perpajakan pada UMKM, serta membantu pelaku usaha UMKM dalam menghitung, memperhitungkan, menyetor, dan melaporkan sendiri kewajiban pajaknya dengan benar agar dapat memenuhi kewajiban perpajakannya dan meningkatkan kesadaran dan pentingnya UMKM dalam pembangunan negara.

\section{METODE}

UMKM yang akan dilakukan penambahan kompetensi perhitungan dan pelaporan pajak adalah hanya di Kota Cilegon Provinsi Banten. Metode yang digunakan dalam pengabdian masyarakat ini dilakukan dengan beberapa tahap. Tahap pertama yaitu melakukan sosialisasi mengenai peran UMKM dalam pembangunan, sehingga dapat meningkatkan kesadaran dan pengetahuan pelaku UMKM mengenai peran mereka akan pentingnya pajak dalam pembangunan negara. Tahap kedua yaitu sosialisasi alasan membuat NPWP dan pelatihan cara pembuatan NPWP agar dapat meningkatkan pemahaman pelaku UMKM tentang kegunaan dari NPWP dalam pelaporan kewajiban perpajakannya. Tahap ketiga yaitu praktik pelaksanaan kewajiban perpajakan mulai dari menghitung menyetorkan dan melporkan pajak. Praktik pelaksanannya dilakukan dengan pelatihan dan pendampingan perhitungan pajak, tutorial pembayaran pajak dan pelatihan pelaporan pajak dengan sitem e-filling. Metode praktik dilakukan dengan mengajak peserta UMKM untuk melakukan secara langsung tahapan dalam pemenuhan kewajiban perpajakan yang bertujuan untuk melihat sejauh mana daya serap masing-masing peserta dalam menerima materi yang telah disampaikan. Kegiatan diskusi dipilih sebagai teknik penyampaian informasi agar tercipta komunikasi dua arah yang efektif dan penyampaian informasi tidak membosankan.

\section{HASIL DAN PEMBAHASAN}

Kegiatan pengabdian ini di awali dengan melakukan sosialisasi mengenai peran UMKM dalam pembangunan, sehingga dapat meningkatkan kesadaran dan pengetahuan pelaku UMKM mengenai peran mereka akan pentingnya pajak dalam pembangunan negara. Dengan adanya kegiatan sosialisasi tersebut diharapkan meningkatnya jumlah kesadaran UMKM untuk membayar pajak dan pengetahuan tentang manfaat pajak bagi masyarakat dapat meningkat. 


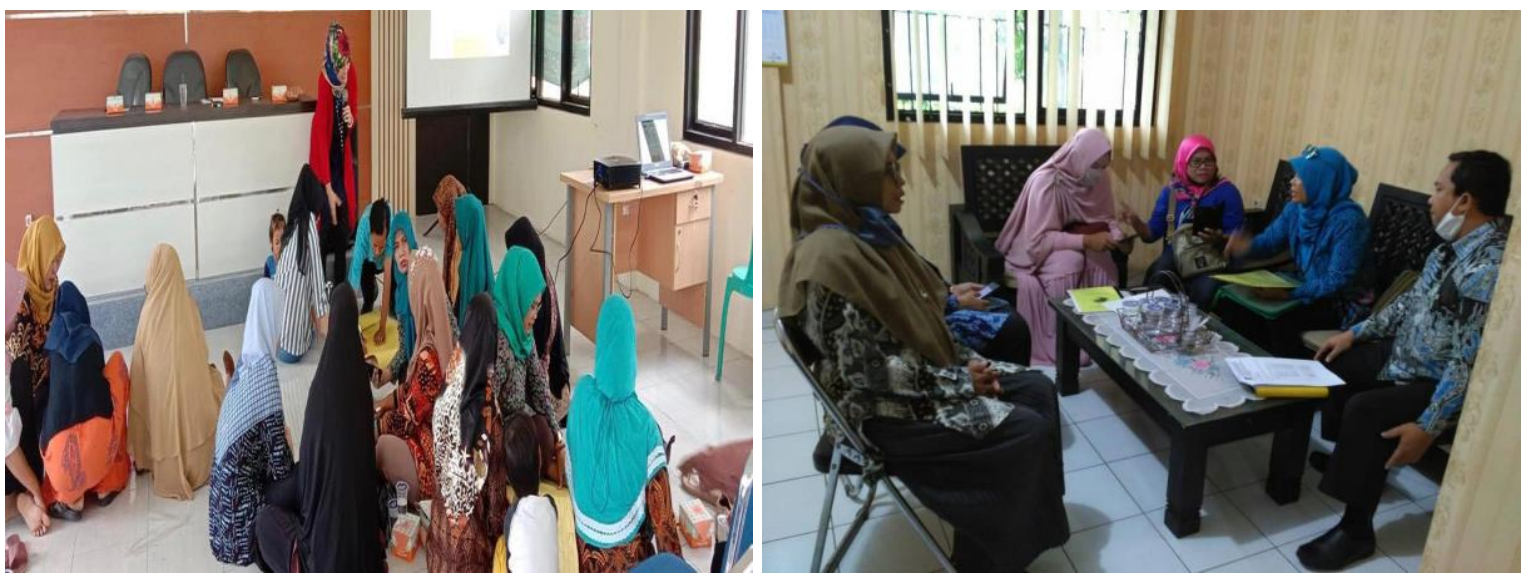

Gambar 1 Sosialisasi Peran UMKM Dalam Pembangunan

Tahapan selanjutnya setelah dilakukan sosialisasi yaitu diadakan pelatihan dan pendampingan pajak UMKM. Kegiatan pelatihan dan pendampingan dilaksanakan untuk membantu para pelaku UMKM yang bingung dalam pembuatan NPWP maupun yang kesulitan dalam melapor maupun menghitung pajaknya. Adapun tahapan kegiatan pelatihan pajak yaitu:

1. Pemberian materi oleh narasumber pajak dari Kantor Pelayanan Pajak (KPP) kota Cilegon

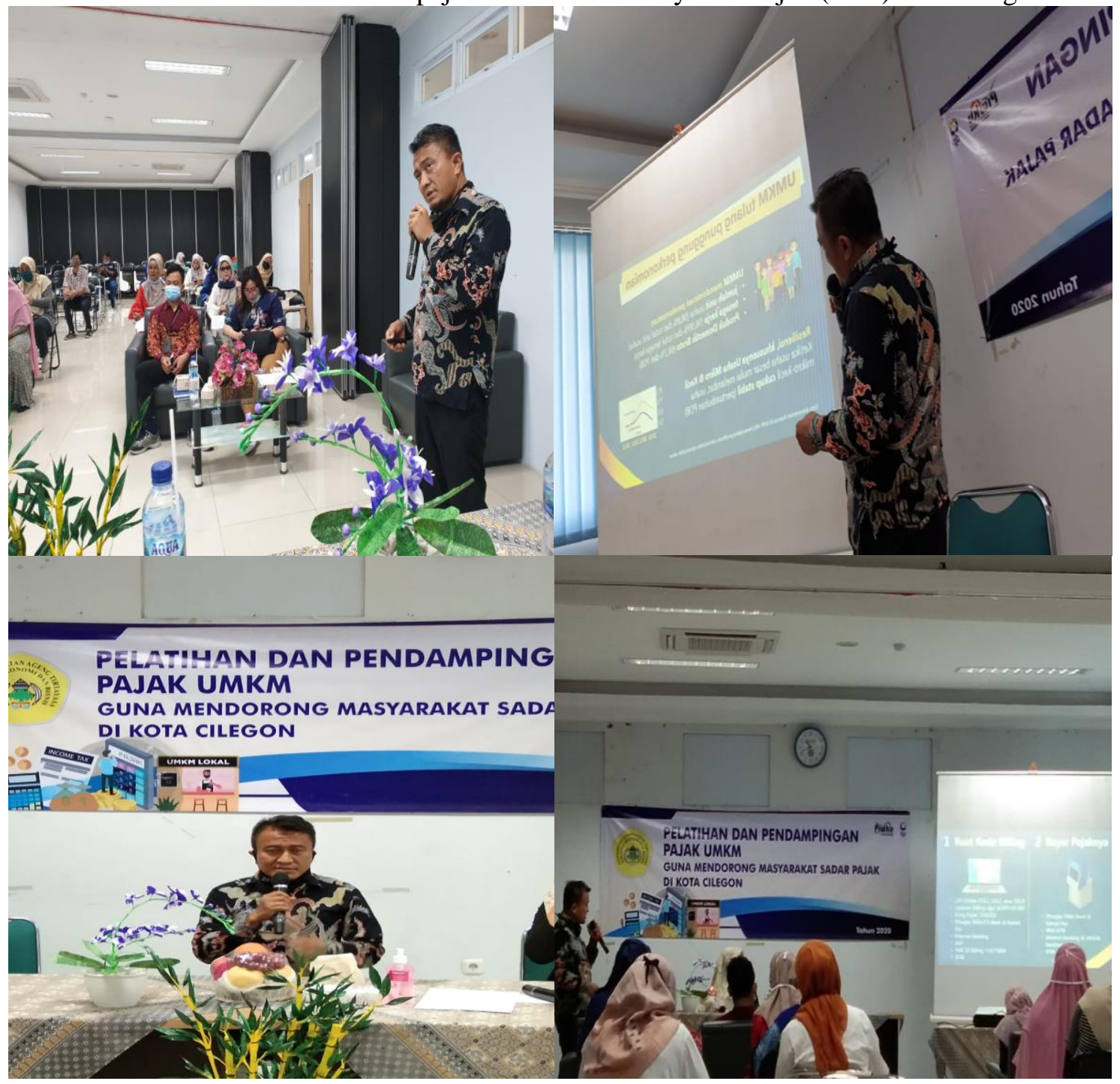

Gambar 2 Pemberian Materi Pelatihan Pajak UMKM 
Pemberian materi ini dilakukan dengan memaparkan materi terkait cara pembuatan NPWP, cara pembayaran pajak yang dapat dilakukan dengan mudah melalui petugas teller bank dan kantor pos, atm, internet banking dan mobile banking sampai pemberian materi tentang tata cara pelaporan pajak UMKM. Kegiatan ini tidak mendapat hambatan yang berarti saat penyampaian materi hingga diskusi dengan para pelaku UMKM. Narasumber memberikan penjelasan terkait PP 23 tahun 2018. Peraturan ini menjelaskan tentang Pajak Penghasilan atas Penghasilan dari Usaha yang Diterima atau Diperoleh Wajib Pajak yang Memiliki Peredaran Bruto Tertentu. Narasumber memaparkan materi-materi terkait:

a. Subjek dan objek pajak

b. Wajib Pajak siapa saja yang tidak dikenakan PP 23 tahun 2018.

c. Cara Pelunasan Pajak

d. Langkah-langkah pelaksanaan PP 23 tahun 2018 yaitu mulai dari:

- Cara daftar NPWP dan persyaratan pendaftarannya

- Cara menghitung pajak peredaran bruto tertentu

- Cara Lapor

- Cara Pembayaran

Dalam kegiatan pelatihan ini para peserta UMKM sangat antusias karena masih ada beberapa dari para pelaku UMKM tersebut yang belum memahami terkait peraturan pemerintah nomor 23 tahun 2018 tersebut.
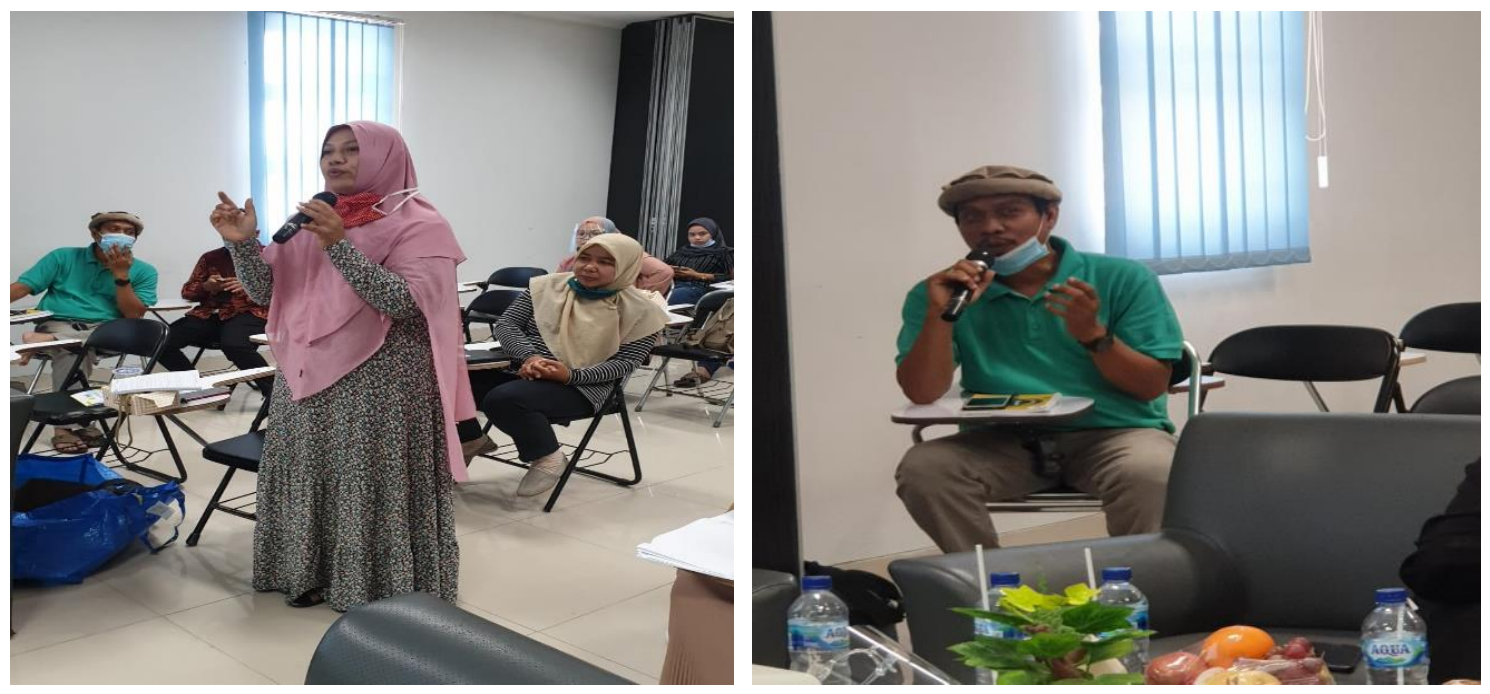

Gambar 3 Peserta Bertanya Terakit Pajak UMKM

Beberapa temuan penting yang ditemukan dalam kegiatan pengabdian pada masyarakat UMKM Kota Cilegon yaitu:

1. Masih ada pelaku UMKM yang belum melakukan pencatatan keuangan secara lengkap dan masih ada yang belum paham dalam melakukan pencatatan laporan keuangannya.

2. Masih ada pelaku UMKM yang bingung cara membuat NPWP dikarenakan keterbatasan informasi terkait syarat-syarat apa saja yang diperlukan dalam pembuatan NPWP tersebut.

3. Masih terdapat pelaku UMKM yang bingung cara menghitung dana melapor pajaknya dikarenakan belum memahami dan omset usahanya masih sangat minim sehingga mereka masih belum melaporkan pajak UMKM.

Dari beberapa temuan di atas, juga terdapat beberapa pelaku UMKM yang sudah memiliki NPWP dan sudah pernah melaporkan pajaknya tetapi masih ada yang belum mengenal terkait Peraturan Pemerintah Nomor 23 Tahun 2018. Oleh karena itu dilakukan pemberian materi terkait pajak UMKM terkait Peraturan Pemerintah Nomor 23 tahun 2018 yaitu tarif 0,5\% bagi UMKM yang memiliki peredaran bruto usaha di bawah 4,8 milyar pertahun. Kegiatan ini sekaligus memberitahukan kepada pelaku usaha UMKM bahwa selama masa pandemi covid-19, pelaku 
UMKM mendapat insentif dari pemerintah terkait pembebasan pajak usahanya sampai bulan Desember 2020. Pelaku usaha mikro, kecil, dan menengah (UMKM) yang ingin memanfaatkan insentif ini hanya perlu menyampaikan laporan realisasi dan tidak perlu mengajukan Surat Keterangan Peraturan Pemerintah Nomor 23 tahun 2018. Dengan adanya berbagai permasalahan yang terkait dengan kewajiban perpajakan wajib pajak khususnya UMKM , maka pengabdian dalam bentuk pelatihan ini sangat penting dilakukan, agar wajib pajak terhindar dari sanksi perpajakan, mendorong kepatuhan wajib pajak sehingga penerimaan negara dari sektor pajak bisa meningkat.

\section{Pelatihan dan Pendampingan Pajak UMKM}

Pelatihan dan pendampingan Pajak UMKM dilaksanakan untuk membantu para pelaku UMKM dalam memahami materi pelatihan yang telah di dapat. Membantu dan membimbing pelaku UMKM yang belum memiliki NPWP agar menyiapkan persyaratan yang telah dipaparkan dalam materi pelatihan untuk dapat mendaftar NPWP. Mendampingi pelaku UMKM yang belum memahami cara perhitungan, pembayaran hingga pelaporan pajak terutangnya.
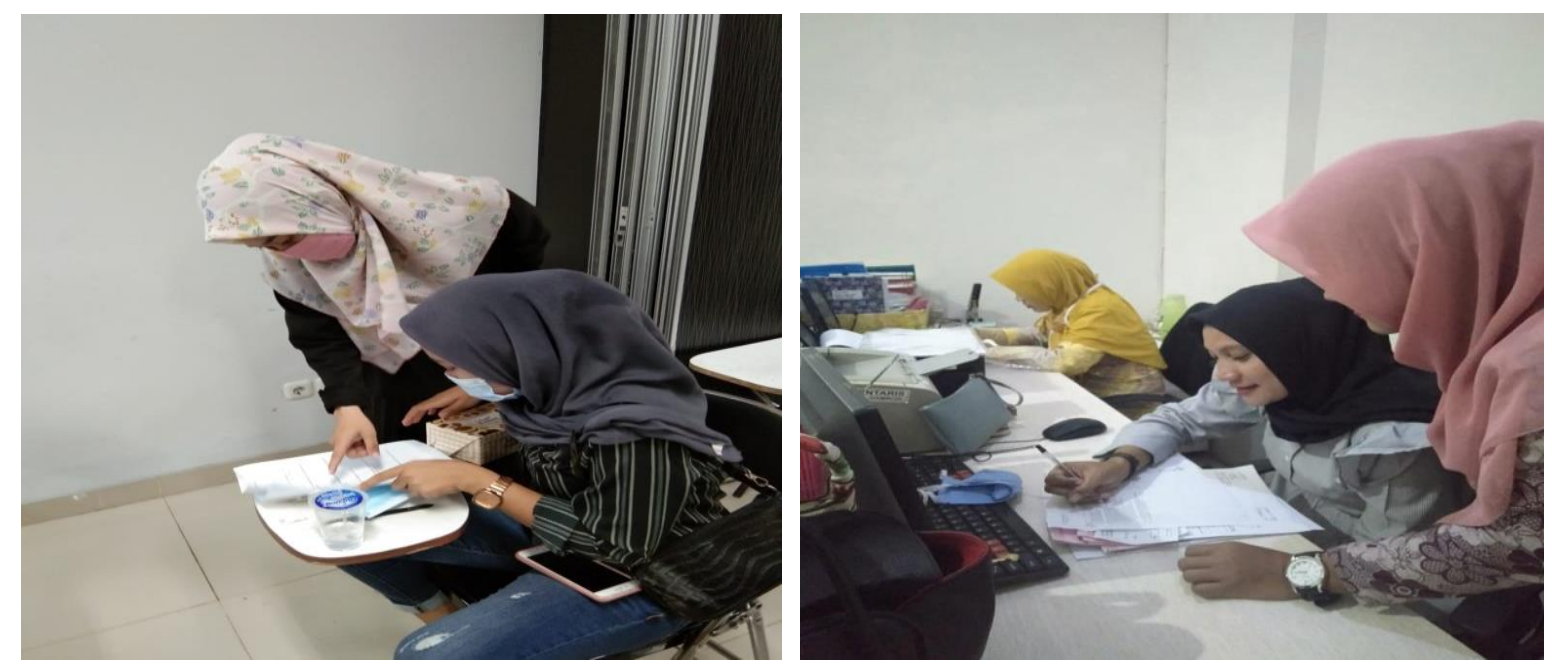

Gambar 4 Pelatihan dan Pendampingan Perhitungan dan Pelaporan Pajak UMKM

Kegiatan pelatihan ini dilakukan dengan memberikan beberapa contoh kasus cara perhitungan menggunakan tarif PPh final sesuai dengan PP 23 tahun 2018. Kegiatan pelatihan dan pendampingan pajak ini juga dilakukan dengan mengajak peserta untuk mencoba secara langsung menghitung pajak serta tahapan dalam pemenuhan kewajiban perpajakan yang bertujuan untuk melihat sejauh mana daya serap masing-masing peserta dalam menerima materi yang telah disampaikan.

Selain memberikan materi terkait pajak UMKM, kegiatan pengabdian ini juga memberikan materi terkait pengembangan usaha UMKM. Kegiatan ini dilakukan untuk memberikan cara-cara agar usaha para pelaku UMKM dapat lebih berkembang. Narasumber dalam kegiatan ini yaitu diisi oleh Direktur Piwku. Materi yang disampaikan sangat inspiratif dan pemateri menjelaskan terkait sinergi pentahelix. Keberhasilan pengembangan UMKM di Indonesia sangat bergantung kepada langkah kolaboratif stakeholder di Indonesia, yakni academy, business, government, community dan media. 

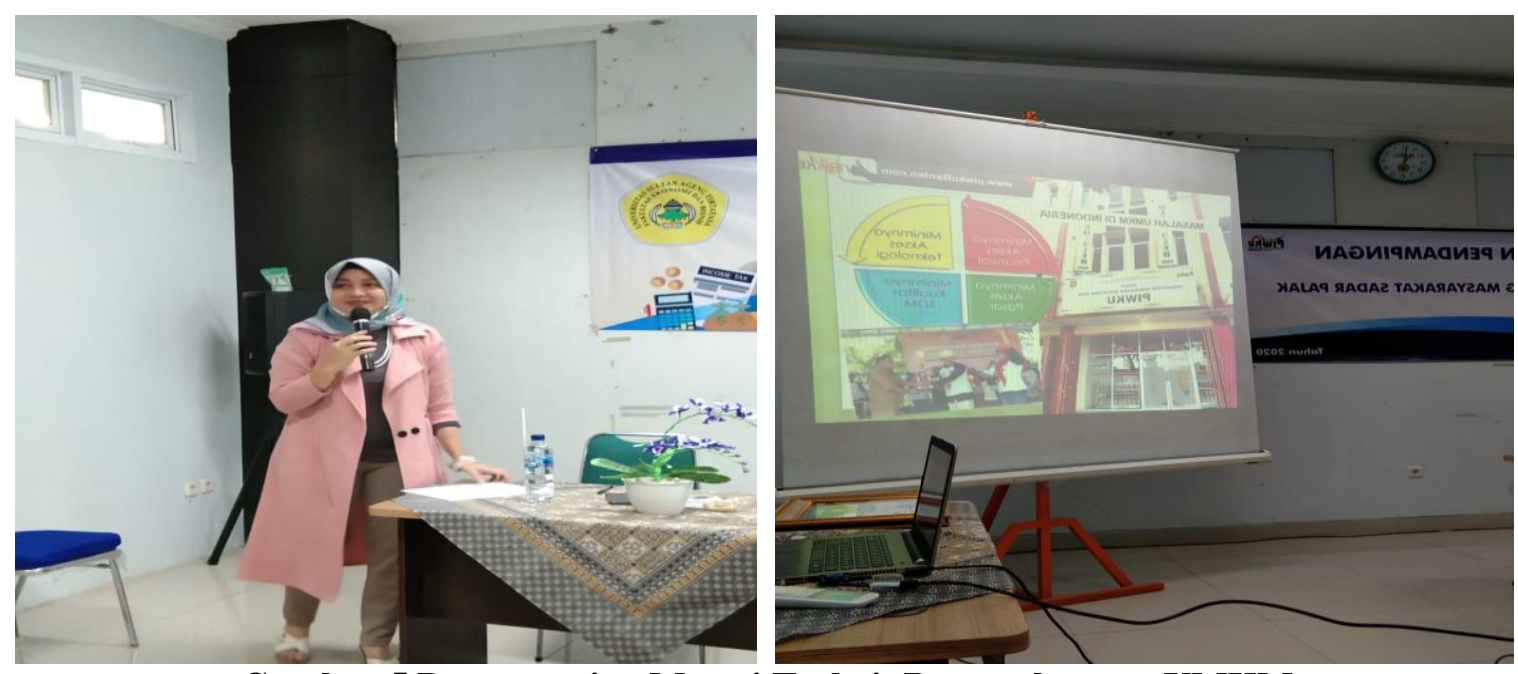

Gambar 5 Penyampaian Materi Terkait Pengembangan UMKM

Materi terkait sinergi pentahelis ini meliputi academy, business, government, community dan media. Akademisi sebagai Centre of excellence akademisi terdiri dari unsur dosen, mahasiswa, dan peneliti dari berbagai perguruan tinggi. Bisnis yaitu pengusaha dan asosiasi pengusaha ataupun asosiasi profesi semua bidang. Government berperan untuk melindungi sekaligus sebagai inisiator dan motivator terbukanya peluang pasar baru bagi produk UMKM, juga sebagai fasilitator dan enabler kepada semua stakeholder yang terlibat dalam perencanaan, pelaksanaan, pemantauan dalam pemberdayaan UMKM. Komunitas merupakan wadah menjembatani unsur-unsur kesamaan minat dan pola pikir sehingga memudahkan sinergi, berbagi inspirasi dan menyampaikan aspirasi, dan secara luas masyarakat adalah konsumen sekaligus sebagai penyedia Sumber Daya Manusia. Terkahir adalah media yaitu berfungsi sebagai sosialisasi (penyebaran informasi) dan sarana edukasi berbasis media (cetak, audio visual, online).

\section{SIMPULAN}

Kegiatan pengabdian ini bertujuan untuk memberikan pelatihan dan pendampingan bagi UMKM dengan memberikan pemahaman tentang konsep dasar perpajakan, cara menghitung, membayar dan menyampaikan kewajiban perpajakannya. Kegiatan pengabdian ini dapat meningkatkan pengetahuan mengenai peran pelaku UMKM dalam pembangunan. Dengan adanya kegiatan ini dapat meningkatkan pengetahuan pelaku UMKM mengenai manfaat NPWP, alasan pelaku UMKM harus membayar pajak, serta manfaat pajak. Kegiatan pengabdian ini menemukan alasan UMKM tidak membuat NPWP karena tidak mengetahui cara pembuatannya dan keterbatasan informasi terkait syarat-syarat apa saja yang diperlukan dalam pembuatan NPWP tersebut. Kegiatan pengabdian ini juga menemukan bahwa pelaku UMKM belum melakukan pencatatan keuangan secara lengkap dan masih ada yang belum paham dalam melakukan pencatatan laporan keuangannya. Kegiatan pengabdian ini menemukan bahwa pelaku UMKM masih bingung cara menghitung dana melapor pajaknya dikarenakan belum memahami cara perhitungan dan pelaporannya dan berpendapat bahwa omset usahanya masih sangat minim sehingga mereka masih belum melaporkan pajak UMKM. Kegiatan pengabdian ini menemukan bahwa pelaku UMKM tidak melaksanakan Peraturan Pemerintah Nomor 23 Tahun 2018, bukan berarti mereka sengaja untuk tidak melaksanakan, namun ternyata karena ketidaktahuan mereka pada peraturan ini.

\section{SARAN}

Kegiatan pengabdian kepada masyarakat ini dilakukan dalam periode yang relatif singkat sehingga masih terdapat adanya risiko kesalahan yang dilakukan oleh para pelaku UMKM dalam memenuhi kewajiban perpajakannya mulai dari menghitung pajak terutang, membayar, dan melaporkan pajak. Oleh karena itu, kegiatan pengabdian kepada masyarakat yang dilakukan kepada para pelaku UMKM perlu dilakukan dalam waktu yang lebih panjang untuk memastikan bahwa pelaku UMKM telah melaksanakan kewajiban sesuai ketentuan peraturan perpajakan. 


\section{UCAPAN TERIMA KASIH}

Penulis mengucapkan terima kasih yang sebesar-besarnya kepada Universitas Sultan Ageng Tirtayasa yang telah memberikan bantuan dana melalui skim Pengabdian Pada Masyarakat. Penulis juga mengucapkan terima kasih kepada mitra yang sangat membantu dalam kegiatan ini sehingga dapat berjalan dengan lancar dan kepada KPP Kota Cilegon yang membantu dalam memberikan materi terkait pajak UMKM.

\section{DAFTAR PUSTAKA}

Firmansyah, A, dkk. (2019). Edukasi dan Pendampingan Pelaksanaan Kewajiban Perpajakan Usaha Mikro, Kecil dan Menengah Pada UMKM XYZ. Jurnal Pengabdian Masyarakat. Vol. 1 No. 1. E-ISSN: 2714-691X OJS: http://ojs.itb-ad.ac.id/index.php/IK

Fitria, P. N., \& Supriyono, E. (2019). Pengaruh pemahaman peraturan perpajakan, persepsi tarif pajak, dan keadilan perpajakan terhadap kepatuhan wajib pajak. Ecobank: Journal of Economics and Banking, 1 (1), 47-54.

Hidayatullah, A \& Fatma, F. D. (2019). Sosialisasi Peran UMKM dan Peraturan Pemerintah Nomor 23 Tahun 2018 Guna Mendorong Masyarakat Sadar Pajak. Jurnal Pengabdian Untuk Mu Negeri. Vol. 3 No.1. ISSN: 2550-0198.

Kementerian Koperasi dan Usaha Kecil dan Menengah. (2018). Perkembangan Data Usaha Mikro, Kecil, Menengah (UMKM dan Usaha Besar (UB) tahun 2017-2018. Diakses tanggal 17 April 2020 dari http://www.depkop.go.id/uploads/laporan/1580223129.

Mustofa, F.A, Kertahadi, \& R Maulinarhadi, M. (2016). Pengaruh Pemahaman Peraturan Perpajakan, Tarif Pajak dan Asas Keadilan terhadap Kepatuhan Wajib Pajak (Studi Pada Wajib Pajak Usaha Mikro, Kecil dan Menengah yang Berada di Wilayah Kerja Kantor Pelayanan Pajak Pratama Batu Setelah Diberlakukannya Peraturan Pemerintah No 46 Tahun 2013. Jurnal Perpajakan (JEJAK). Vol. 8 No. 1. perpajakan.studentjournal.ub.ac.id.

Okefinance. 2019. Sri Mulyani Minta Kontribusi UMKM ke Penerimaan Pajak Makin Besar. https://economy.okezone.com/read/2019/04/30/20/2049962/sri-mulyani-minta-kontribusiumkm-ke-penerimaan-pajak-makin-besar diakses tanggal 17 April 2020.

Republik Indonesia. 2018. Peraturan Pemerintah Nomor 23 tahun 2018 tentang Pajak Penghasilan atas Penghasilan dari Usaha yang Diterima atau Diperoleh Wajib Pajak yang Memiliki Peredaran Bruto Tertentu.

Putri, T., Saerang, D. P. E., \& Budiarso, N. S. (2019). Analisis perilaku wajib pajak UMKM terhadap pelaksanaan pemungutan pajak dengan menggunakan self assessment system di Kota Tomohon. Jurnal Riset Akuntansi Going Concern, 14 (1), 130-136.

Sandra, A dkk. (2019). Pendampingan Pajak UMKM: Masalah dan Solusinya. Academics in Action Journal. Volume 1, Number 1, 2019, 1-7.

Supadmi, N.L, dkk (2018). Pelatihan Perhitungan Pajak Penghasilan Terutang Bagi Wajib Pajak UMKM dengan Penghasilan Bruto Tertentu Menurut Peraturan Pemerintah Nomor 46 tahun 2013. Buletin Udayana Mengabdi. Vol.17 No.1. https://doi.org/10.24843/BUM.2018.v17.i01.p25

Tandilino, A, Firman, A \& Rostin (2016). Penerapan Pajak Dalam Meningkatkan Penerimaan Pajak Penghasilan Final Sektor UMKM di Kota Kendari. Jurnal Progres Ekonomi Pembangunan. Vol.1 No.1, e-ISSN: 2502-5171. 